\title{
PARTIAL CHARACTERIZATION OF COLD ACTIVE AMYLASES AND PROTEASES OF STREPTOMYCES SP. FROM ANTARCTICA
}

\author{
Mihaela Cotârleț ${ }^{1}$, Teodor Gh. Negoiță ${ }^{1}$, Gabriela E. Bahrim², Peter Stougaard $^{3}$ \\ ${ }^{1}$ Romanian Polar Research Institute, Bucharest, Romania; ${ }^{2}$ University “Dunărea de Jos”, Faculty of Food Science and \\ Engineering, Bioengineering Department, Galați, Romania; ${ }^{3}$ University of Copenhagen, Faculty of Life Sciences, Department of \\ Agriculture and Ecology, Denmark. \\ Submitted: July 11, 2010; Returned to authors for corrections: September 02, 2010; Approved: March 14, 2011.

\begin{abstract}
The aim of this study was to isolate novel enzyme-producing bacteria from vegetation samples from East Antarctica and also to characterize them genetically and biochemically in order to establish their phylogeny. The ability to grow at low temperature and to produce amylases and proteases cold-active was also tested. The results of the 16S rRNA gene sequence analysis showed that the 4 Alga rRNA was 100\% identical to the sequences of Streptomyces sp. rRNA from Norway and from the Solomon Islands. The Streptomyces grew well in submerged system at $20^{\circ} \mathrm{C}$, cells multiplication up to stationary phase being drastically increased after $120 \mathrm{~h}$ of submerged cultivation. The beta-amylase production reached a maximum peak after seven days, while alpha-amylase and proteases were performing biosynthesis after nine days of submerged cultivation at $20^{\circ} \mathrm{C}$. Newly Streptomyces were able to produce amylase and proteases in a cold environment. The ability to adapt to low temperature of these enzymes could make them valuable ingredients for detergents, the food industry and bioremediation processes which require low temperatures.
\end{abstract}

Key words: Streptomyces sp., East Antarctica, cold-adapted strain, cold active proteases and amylase

\section{INTRODUCTION}

Extremozymes have great economic potential in many industrial processes - detergents, textiles, baking, brewing, starch, animal food, leather and the pulp industries, including agricultural, chemical, and pharmaceutical applications $(15,5)$. Among extremozymes, cold-active enzymes have important biotechnological applications in the food industry, as well as in biomass conversion and bioremediation. Running processes at low temperatures reduces risk of contamination by mesophiles and also saves energy $(33,16,13,28,27)$.

Therefore, researchers are now trying to exploit extremophiles as valuable source of novel enzymes (6). Particular enzymes who display highly specific activity and catalytic efficiency at low temperatures have the capability to adapt to cold habitats. (31). Among the extremophiles, cold-

*Corresponding Author. Mailing address: Dunãrea de Jos University, Domnească Street, no 111, 800821, Galąti, Romania.; Tel.: 0040741537336.; E-mail: : Mihaela.Cotarlet@ugal.ro / mihaela_scantee@yahoo.com 
adapted organisms such as psychrophiles and psychrotrophs inhabit both terrestrial and aquatic environments in polar and alpine regions, in the bulk of the ocean, in shallow subterranean regions, in the upper atmosphere, in refrigerated environments, and on plants and animals living in cold regions. Psychrotolerant organisms grow well at temperatures close to the freezing point of water, but have the fastest growth rates above $20^{\circ} \mathrm{C}$, whereas psychrophilic organisms grow faster at a temperature of $15^{\circ} \mathrm{C}$ or lower, but are unable to grow above $20^{\circ} \mathrm{C}(26,25,31)$.

Amylases (endo-1,4- $\alpha$-D-glucanohydrolases EC 3.2.1.1) represent $25 \%$ of the sales in enzyme market. These enzymes play a vital role in many industrial manufacturing processes such as textile, paper, food industries and detergents $(6,18,35$, 38). Proteases are industrially important enzymes also having wide applications in the manufacture of pharmaceuticals, leather, silk, detergents, food, the waste processing industries, diagnostics and for the recovery of silver used in X-ray films $(33,20)$.

The possibility of using actinomycetes, especially Streptomyces for enzyme production has recently been investigated. Streptomyces genus exhibits remarkable capacity for the synthesis of many valuable enzymes with attractive properties $(39,6,38)$. Streptomyces species have served as an important source of numerous secondary metabolites, enzymes (9) and antibiotics (1) mainly due to their shorter generation time, and the ease of genetic and environmental manipulation. Literature offers valuable information on streptomycetes species able to produce proteases. In particular S. clavuligerus, S. griseus, S. moderatus, S. rimosus, S. thermoviolaceus, S. thermovulgaris, S. avermectinus, and S. pactum DSM 40530 (36, 1, 23), S. gulbargensis (10) are able to produce proteases, while $S$. fradie, S. griseus, S. lividans, S. peptidofaciens, and $S$. rimosus are known as aminopeptidase producers. Alphaamylases have been also produced with $S$. aureofaciens, $S$. rimosus, S. gulbargensis, S. hygroscopicus, S. preacox (12, 34, 40). The study of transglutaminase production by Streptomyces higroscopus, Streptomyces mobaraensis, S. libani, Streptoverticillium mobaraense is more recent $(11,37,24,30$, $8)$.

Due to the insufficiency of information regarding useful cold-active enzymes and the industrial application of the psychrophilic and psychrotrophic taxa it is imperative to isolate new cold-adapted bacteria and to identify production of coldadapted amylase and proteases.

Herein we characterize genetically and biochemically a polar streptomycete 4 Alga, we examine its growth behaviour and also the production of amylases and proteases at low temperature.

\section{MATERIALS AND METHODS}

\section{Microorganism and growth properties}

The selected bacterial coded 4 Alga was isolated from Antarctic vegetation samples from Progress Lake 2, Larsemann Hills, East Antarctica (Negoita T. Gh.) (7). The stock cultures were maintained on Gause-agar medium with the following composition (g/l): starch 20, $\mathrm{K}_{2} \mathrm{HPO}_{4} 0.5, \mathrm{MgSO}_{4} \cdot 7 \mathrm{H}_{2} \mathrm{O} 0.5$, $\mathrm{KNO}_{3}$ 1.0, $\mathrm{NaCl} 0.5, \mathrm{FeSO}_{4} \cdot 7 \mathrm{H}_{2} \mathrm{O} 0.01$, agar 25.0, pH 7.2-7.4 (6).

Growth kinetic and enzyme biosynthesis were performed in a submerged system. A liquid medium with following composition (g/l): soluble starch 20.0, corn steep liquor 10.0, $\left(\mathrm{NH}_{4}\right)_{2} \mathrm{SO}_{4} 6.0, \mathrm{CaCO}_{3} 8.0, \mathrm{NaCl} 5.0$ and soybean oil $0.2 \mathrm{ml}$, pH 7.0 (7) was inoculated with $2 \%$ spore suspension and incubated during 15 days, at $20^{\circ} \mathrm{C}$ and $7.276 \mathrm{x}$ g. Growth kinetic was acquired by measuring the cell density at a wavelength of $610 \mathrm{~nm}$ with spectrophotometer UV-VIS, JENWAY.

\section{Morphological and biochemical characterization}

The morphology of the 4 Alga strain was assessed by the colonies formed on Gause agar medium and by contrast phase microscopy using Olympus equipment (Japan). The 
biochemical properties were characterised by using the Biolog microtiter plate in accordance with the manufacturer's instructions. The results were interpreted as positive reaction (+) or negative reaction (-) after $24 \mathrm{~h}$ incubation at $20^{\circ} \mathrm{C}$.

\section{S rRNA gene amplifications and sequencing}

Genomic DNA was isolated from the 4 Alga strain using the Power Soil ${ }^{\circledR}$ DNA Isolation Kit (Mo Bio Laboratories, Inc.). Isolation of the $16 \mathrm{~S}$ rRNA gene was carried out by means of PCR with the primer pair 27F/1492R (22). PCR was performed in a $25 \mu \mathrm{l}$ reaction mixture containing $2.5 \mu \mathrm{l} 10 \mathrm{X}$ buffer (without $\mathrm{MgCl}_{2}$ ), $1.25 \mu \mathrm{MgCl}_{2}(25 \mathrm{mM}$ ), $0.25 \mu \mathrm{ldNTP}$ (25 mM), $0.25 \mu \mathrm{l}$ Taq polymerase (5 units/ $\mu \mathrm{l}$ ) (Ampliqon), 1.0 $\mu \mathrm{l}$ of each of the primers $27 \mathrm{~F}$ and 1492R. Amplification was performed with an initial denaturising step $\left(5 \mathrm{~min}\right.$ at $\left.94^{\circ} \mathrm{C}\right)$, followed by 30 cycles of $94^{\circ} \mathrm{C}$ for $30 \mathrm{sec} ., 55^{\circ} \mathrm{C}$ for $1 \mathrm{~min}$ and $72^{\circ} \mathrm{C}$ for $1 \mathrm{~min}$ and a final extension at $72^{\circ} \mathrm{C}$ for $5 \mathrm{~min}$. The amplified fragments were purified from agarose gels using QIAquick gel extraction kit (QIAGEN) and inserted into the cloning vector $\mathrm{pCR}^{\circledR} 2.1 \mathrm{TOPO}$ according to the manufacturer's instructions. Inserts in $\mathrm{pCR}^{\circledR} 2.1$ TOPO were sequenced at GATC Biotech AG, Germany, and the DNA sequences were submitted to GenBank/EMBL/DDBJ with the accession numbers EF571003, EF571002, EU263063 and GQ924533.

\section{Phylogenetic analysis}

Related sequences were retrieved from public databases using BLAST at the NCBI server (http://www.ncbi.nlm.nih.gov/blast/). The closest related $16 \mathrm{~S}$ rRNA gene sequences were aligned with the sequences of the Antarctic isolate using the alignment algorithm in the CLC Main Workbench 5.1 (CLC bio, Denmark).

\section{Amylase and proteases assays}

The crude extracts were obtained after cultivation in submerged conditions and biomass separation at 4952x g, for 15 minutes. Proteolytic assay was performed via modified
Anson method using 2\% casein as substrate (2) and proteases activity was expressed as Anson units. One Anson unit is the amount of enzyme which, under the analytical specified conditions (2\% casein as substrate, $\mathrm{pH} 7.0$; for $15 \mathrm{~min}$, at $20^{\circ} \mathrm{C}$ ) hydrolyzed the casein to release, in one minute, the hydrolysis products soluble in the trichloroacetic acid; this provides coloration equivalent, measured as absorbance at 670 $\mathrm{nm}$, to $1 \mu \mathrm{mol}$ of tyrosine, in the presence of the FolinCiocalteau reagent by using a tyrosine standard curve over the range of $0.02-0.24 \mu \mathrm{mol} / \mathrm{ml}$ (14).

Alpha-amylase assay was performed by using an adapted method based on a selective distinction of the hydrolysis products in $0.1 \mathrm{~N}$ Lugol solution. One $\alpha$-amylase unit represents the equivalent of the amount of enzyme which generates a 0.05 decrease in the optical density, for $1 \mathrm{~min}$, measured at $610 \mathrm{~nm}$, of the colour iodine-starch complex, into a $1 \%$ starch solution, at $\mathrm{pH} 7.0$ and $20^{\circ} \mathrm{C}$ (4).

The Shaffer-Somogyi method was used to measure the released maltose with few modifications (32). One $\beta$-amylase unit represents the amount of maltose (in $\mathrm{mg}$ ) produced by one $\mathrm{ml}$ crude extract by using $1 \%$ starch as substrate, at $20^{\circ} \mathrm{C}$ and $\mathrm{pH} 7.0$ for $1 \mathrm{~min}$.

\section{RESULTS}

\section{Phylogenetic analysis}

By cultivation on Gause agar medium the outer surface of colonies was perfectly round initially, but after the fourth day of incubation started to develop white aerial mycelium that appeared powdery and also formed spores. Distinctive substrate mycelium colours were not produced and diffusible extracellular pigment was not formed. Microscopic examination revealed that aerial mycelia were morphologically branched with compact spirals of sporophore.

After genomic DNA separation and purification, the sequence of the 16S rRNA gene was determined in order to achieve the phylogeny. Search for similar sequences in the 
GenBank/EMBL/DDBJ database and subsequent alignment of the retrieved sequences indicated that the DNA sequence showed high similarity (99-100\%) to the known 16S rRNA gene sequences from Streptomyces. The 16S rRNA gene sequence of 4 Alga strain was shown to be $100 \%$ identical to sequences of Streptomyces sp. isolates from Norway (accession no. EU263063) and from Solomon Islands (accession no. GQ924533) and to other Streptomyces (code P2C4 and MIUG 12P members of The Collection of Industrial Microbiology Laboratory of University of Galąti Romania) (Fig. 1 and Table $1)$.

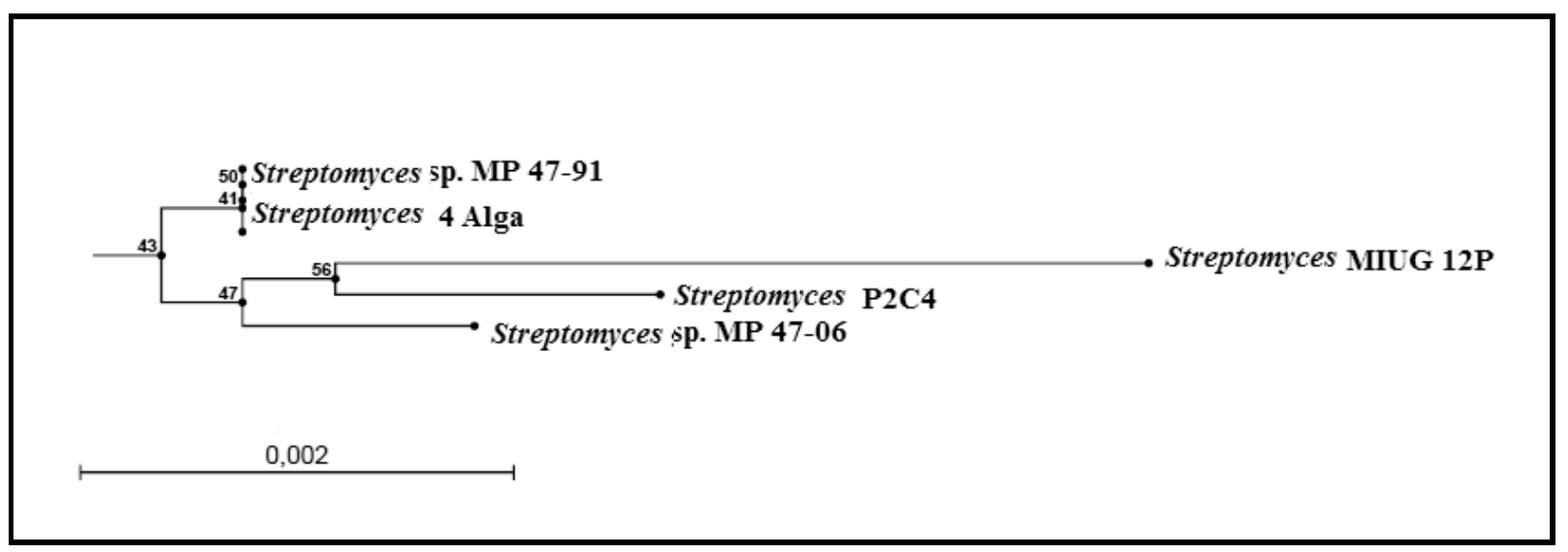

Figure 1. Phylogenetic tree of the 16S rDNA sequence of 4 Alga. The tree was rooted via a neighbor-joining method, and numbers within the dendogram indicate the occurrence $(\%)$ of the branching order in 100 bootstrapped trees.

Table 1. Similarity of $16 \mathrm{~S}$ rRNA gene sequences in the GenBank/EMBL/DDBJ database

\begin{tabular}{|c|c|c|c|c|c|c|c|c|c|c|}
\hline & $\mathbf{1}$ & 2 & 3 & 4 & 5 & 6 & 7 & 8 & 9 & 10 \\
\hline Streptomyces 4 Alga & & 99.93 & 99.93 & 99.93 & 99.93 & 100.0 & 100.0 & 99.80 & 99.80 & 99.60 \\
\hline EF571003 & 99.93 & & 100.0 & 100.0 & 100.0 & 99.93 & 99.93 & 99.87 & 99.73 & 99.53 \\
\hline EF571002 & 99.93 & 100.0 & & 100.0 & 100.0 & 99.93 & 99.93 & 99.87 & 99.73 & 99.53 \\
\hline AF429394 & 99.93 & 100.0 & 100.0 & & 100.0 & 99.93 & 99.93 & 99.87 & 99.73 & 99.53 \\
\hline EU443837 & 99.93 & 100.0 & 100.0 & 100.0 & & 99.93 & 99.93 & 99.87 & 99.73 & 99.53 \\
\hline EU263063 & 100.00 & 99.93 & 99.93 & 99.93 & 99.93 & & 100.0 & 99.80 & 99.80 & 99.60 \\
\hline GQ92453 & 100.00 & 99.93 & 99.93 & 99.93 & 99.93 & 100.0 & & 99.80 & 99.80 & 99.60 \\
\hline EU263062.1 & 99.80 & 99.87 & 99.87 & 99.87 & 99.87 & 99.80 & 99.80 & & 99.73 & 99.53 \\
\hline Streptomyces $\mathrm{P} 2 \mathrm{C} 4$ & 99.80 & 99.73 & 99.73 & 99.73 & 99.73 & 99.80 & 99.80 & 99.73 & & 9953 \\
\hline Streptomyces MIUG 12P & 99.60 & 99.53 & 99.53 & 99.53 & 99.53 & 99.60 & 99.60 & 99.53 & 99.53 & \\
\hline
\end{tabular}

\section{Biochemical characterization of the Streptomyces sp. 4 Alga} isolate

The biochemical properties of Streptomyces 4 Alga were assesed based on their ability to oxidize various carbon sources of the Biolog microtiter plate assay (Table 2). Arabinose, xylose, mannitol, L-phenylalanine were metabolised by the 4
Alga strain. There are many reports regarding utilization of carbon sources by the streptomycetes and in this sense Vonothini et al., (2008) research concerning actinomycete strain, PS-18A isolated from an estuarine shrimp pond sustain our results. Fructose, maltose, dextrin, glycogen, Tween 40, Tween 80, L-arabinose, L-aspartic acid, L-leucine, glycerol, 
citric acid, itaconic acid, D-mannitol, L-histidine, D-serine, Lthreonine were well utilized; sucrose, inositol, trehalose, formic acid, malonic acid, L-alanine, inosine, hydroxy-L-proline were not utilized. These results are also in accordance with Kim et al., (1998) for Streptomyces thermocarboxydovorans sp. nov. and Streptomyces thermocarboxydus sp. nov., two moderately thermophilic carboxydotrophic species from soils.

Table 2. Biochemical properties of the Streptomyces 4 Alga after $24 \mathrm{~h}$ of incubation at $20^{\circ} \mathrm{C}$

\begin{tabular}{|c|c|c|c|}
\hline Principal component & Reaction & Principal component & Reaction \\
\hline$\alpha$-cyclodextrin & + & L-Rhamnose & - \\
\hline Dextrin & + & D-Sorbitol & - \\
\hline Glycogen & + & Sucrose & - \\
\hline Tween 40 & + & D-trehalose & - \\
\hline Tween 80 & + & Turanose & - \\
\hline $\mathrm{N}$-acetyl-D-galactosamine & + & Xylitol & + \\
\hline N-acetyl-D-glucosamine & + & Pyruvic acid methyl ester & + \\
\hline Adonitol & + & Succinic Acid Mono-Methyl-Ester & + \\
\hline L-Arabinose & + & Acetic Acid & + \\
\hline D-Arabitol & + & Cis-Aconitic Acid & + \\
\hline D-Cellobiose & + & Citric Acid & + \\
\hline i-Erythritol & + & Formic Acid & - \\
\hline D-Fructose & + & D-Galactonic Acid Lactone & - \\
\hline L-Fucose & + & D-Galacturonic Acid & - \\
\hline D-Galactose & + & D-Gluconic Acid & - \\
\hline Gentiobiose & - & D-Glucosaminic Acid & - \\
\hline$\alpha$-D-Glucose & - & D-Glucuronic Acid & + \\
\hline m-Inositol & - & $\alpha$-hydroxybutyric Acid & + \\
\hline$\alpha$-D-Lactose & - & $\beta$-hydroxybutyric Acid & + \\
\hline Lactulose & + & $\gamma$-hydroxybutyric Acid & + \\
\hline Maltose & + & p-hydroxy Phenylacetic Acid & + \\
\hline D-Mannitol & + & Itaconic Acid & + \\
\hline D-Mannose & + & $\alpha$-Keto Butyric Acid & + \\
\hline D-Melibiose & + & Hydroxy-L-Proline & - \\
\hline$\beta$-Methyl D-glucoside & + & L-Leucine & + \\
\hline D-Psicose & + & L-Orithine & + \\
\hline D-Raffinose & - & L-Phenylalanine & + \\
\hline$\alpha$-Keto Glutaric Acid & - & L-Proline & + \\
\hline$\alpha$-Keto Valeric Acid & - & L-Pyroglutamic Acid & + \\
\hline D,L-Lactic Acid & - & D-serine & + \\
\hline Malonic Acid & - & L-Serine & + \\
\hline Propionic Acid & - & L-Threonine & + \\
\hline Quinic Acid & + & D,L-Carnitine & + \\
\hline D-Saccharic Acid & + & $\gamma$-Amino Butyric Acid & + \\
\hline Sebacic Acid & + & Urocanic Acid & + \\
\hline Succinic Acid & + & Inosine & - \\
\hline Bromosuccinic Acid & + & Uridine & + \\
\hline Succinamic Acid & + & Thymidine & + \\
\hline Glucuronamide & + & Phenyethyl-amine & + \\
\hline L-Alaninamide & - & Putrescine & + \\
\hline D-Alanine & - & 2-Aminoethanol & + \\
\hline L-Alanine & - & 2,3-Butanediol & + \\
\hline L-Alanyl-glycine & - & Glycerol & + \\
\hline L-Asparagine & - & D,L- $\alpha$-Glycerol Phosphate & + \\
\hline L-Aspartic Acid & + & $\alpha$-D-Glucose 1-Phosphate & + \\
\hline L-Glutamic Acid & + & D-Glucose 6-Phosphate & + \\
\hline Glycyl-L-Aspartic Acid & + & L-Histidine & + \\
\hline Glycyl-L-Glutamic Acid & + & & \\
\hline
\end{tabular}

+ Positive reaction; - negative reaction 
Growth kinetic and time course production of amylases and protease in cold conditions

The Streptomyces 4 Alga is a psychrotolerant strain (data not shown). The data presented in Fig. 2 showed that the Streptomyces 4 Alga was capable to adapt easily to submerged cultivation and that cells multiplication drastically increased in the exponentially growth phase and reached the stationary phase after the five days of submerged cultivation at $20^{\circ} \mathrm{C}$. Previous research (Thumar and Singh, 2007) showed that Streptomyces clavuligerus strain mit-1 reached the stationary phase after $100 \mathrm{~h}$. It can be seen that the optical density is high compared to literature results for Streptomyces sp. D1 from marine sediment samples, which reached the stationary phase after almost six days of submerged cultivation at $45^{\circ} \mathrm{C}$ and 5.502x g (Chakraborty et al., 2008).

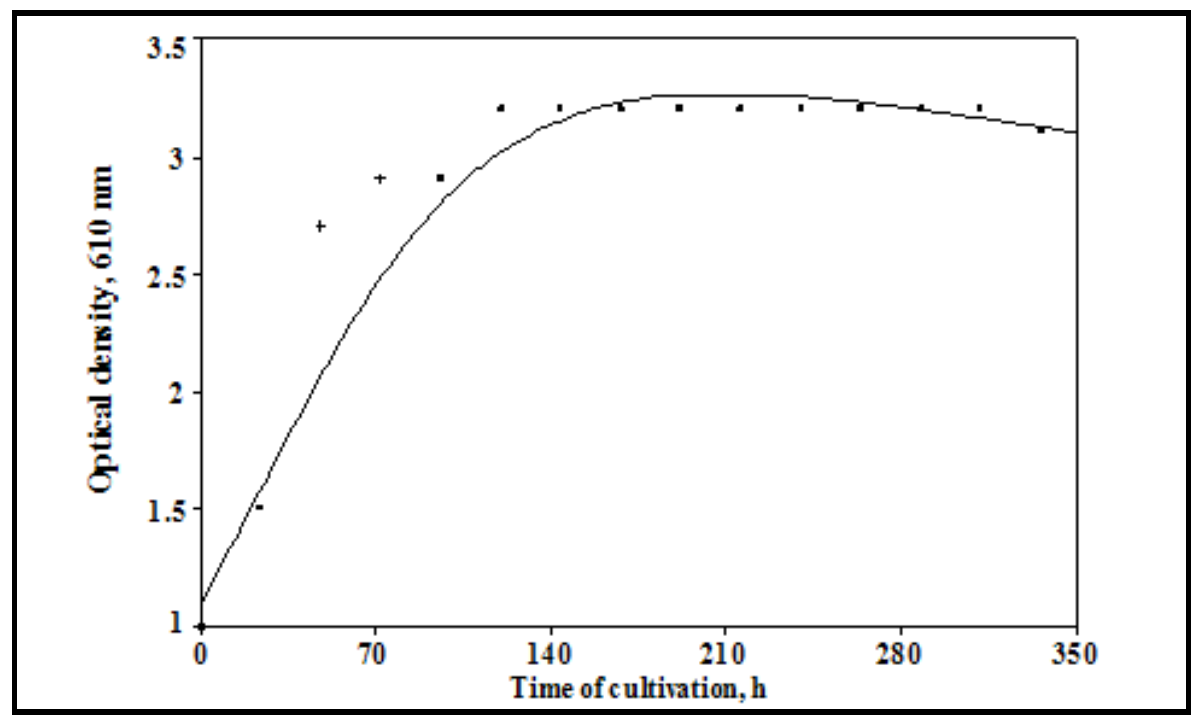

Figure 2. Growth kinetic of Streptomyces 4 Alga in submerged culture, by shaking at 7.276x g. Initial pH 7.0; inoculum $2 \%$ spore suspension; incubation period: 15 days; incubation temperature $20^{\circ} \mathrm{C}$. Data are the average of two parallel replicates.

The production of amylases and proteases was achieved during 15 days of submerged culture at $20^{\circ} \mathrm{C}$. Alpha-amylase was synthesised during the early exponential phase, however the highest yield (14.10 UA) was registered after $216 \mathrm{~h}$ of cultivation, in the middle of the stationary phase. After that the amylase biosynthesis potential remains constant and after 12 days of cultivation amylase biosynthesis slowly decreases (Fig. 3).

These results are in accordance with Chakraborty et al. (2008) who reported that amylase from Streptomyces sp. D1, from marine sediments sampled from coastal region India, reached the optimum production after 11 days of submerged cultivation at $45^{\circ} \mathrm{C}$ and 5.502x g. Syed et al., (2009), referred that amylase from S. gulbargensis DAS 131 reached the maximum of enzyme activity after $48 \mathrm{~h}$ of incubation at $28^{\circ} \mathrm{C}$.

Beta-amylase synthesis started in the middle of the stationary phase. The highest production of beta-amylase, 173.47 UA, was achieved after $168 \mathrm{~h}$ of submerged cultivation, while alpha-amylase biosynthesis was noticed after $216 \mathrm{~h}$ of submerged cultivation (Fig. 4).

The maximum proteases biosynthesis was recorded after nine days of cultivation during the stationary phase (Fig. 5). This result is in agreement with Bascaran et al. (1990) and Moreira et al. (2001) who showed that biosynthesis of 
proteases from Streptomyces clavuligerus starts in the early stationary phase of growth. Filamentous bacteria like Streptomyces rimosus and Streptomyces clavuligerus mit-1 recorded the optimum proteases production at $166 \mathrm{~h} \mathrm{(40)}$ and
$144 \mathrm{~h}$ (36) respectively. These results certify the ability of newly Streptomyces 4 Alga to grow well at low temperature $\left(20^{\circ} \mathrm{C}\right)$ and to produce cold-active amylase (alpha and beta amylase) and proteases.

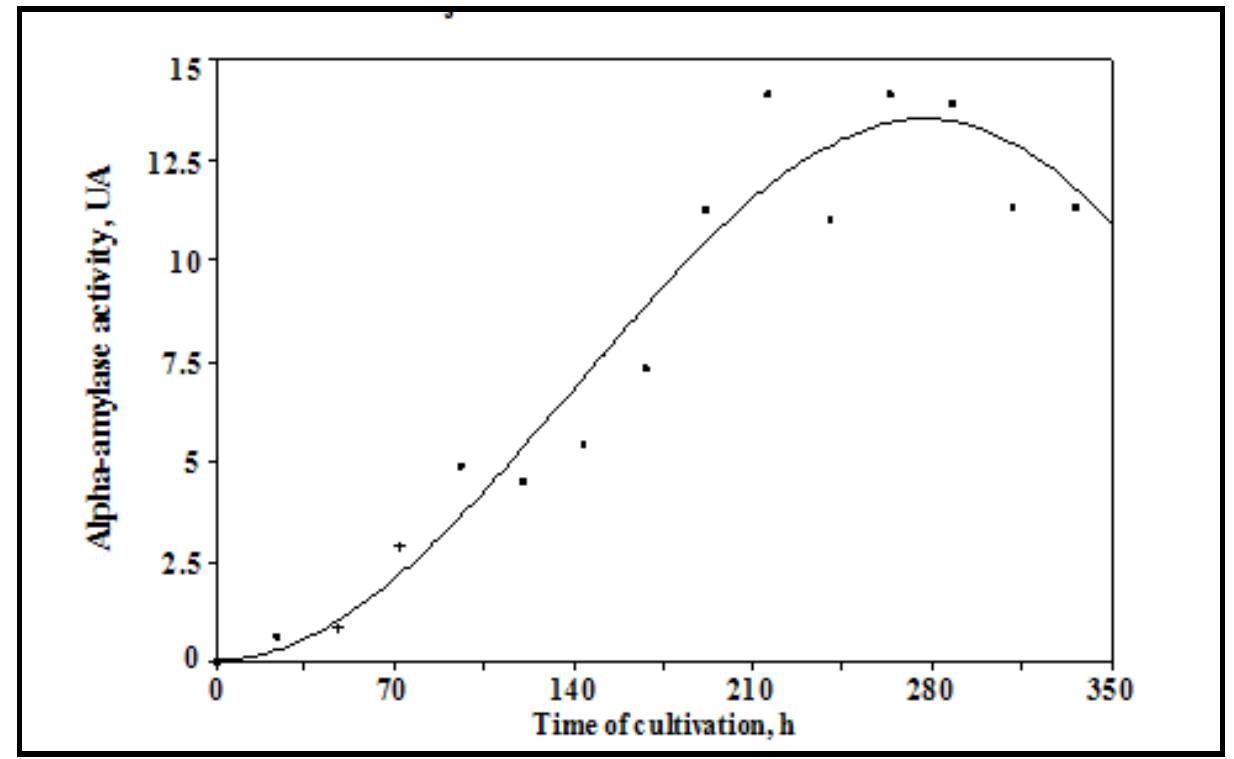

Figure 3. Alpha-amylase production at Streptomyces 4 Alga in submerged culture, by shaking at 7.276x g. Initial pH 7.0; inoculum $2 \%$ spore suspension; incubation period: 15 days; incubation temperature $20^{\circ} \mathrm{C}$. Data are the average of two parallel replicates.

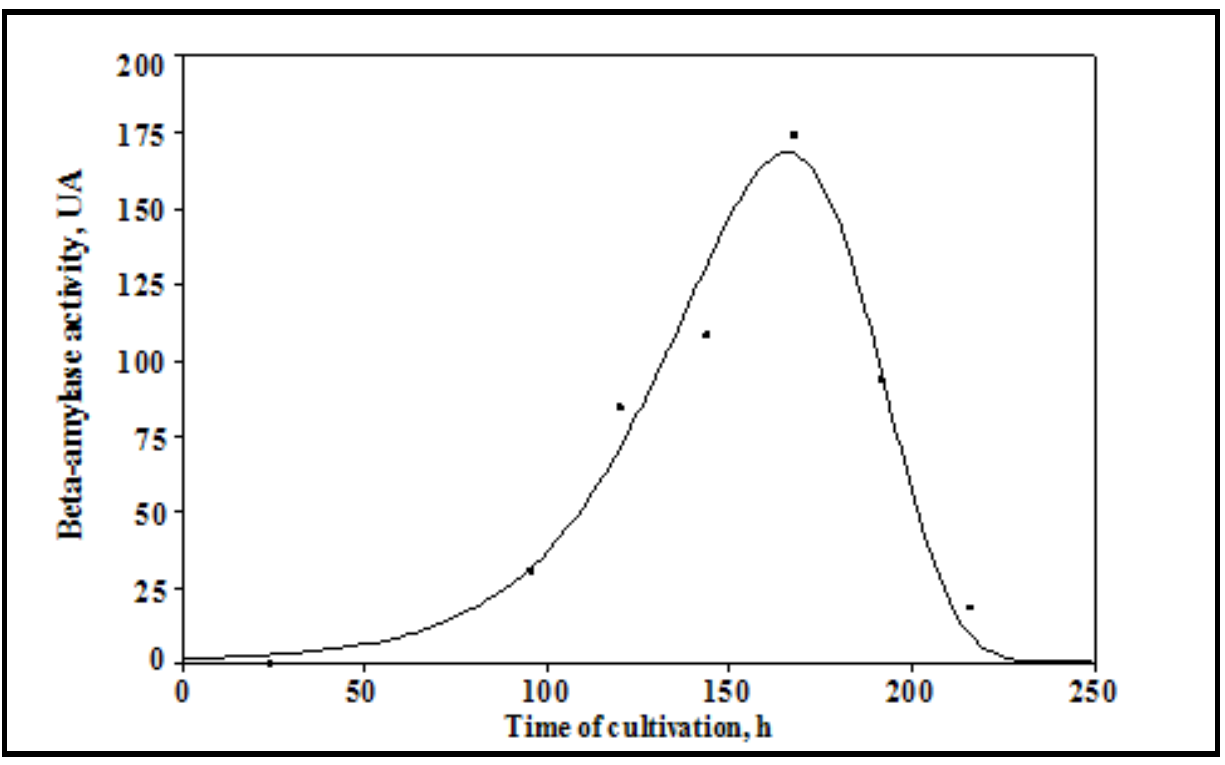

Figure 4. Beta-amylase production at Streptomyces 4 Alga in submerged culture, by shaking at 7.276x g. Initial pH 7.0; inoculum $2 \%$ spore suspension; incubation period: 15 days; incubation temperature $20^{\circ} \mathrm{C}$. Data are the average of two parallel replicates. 


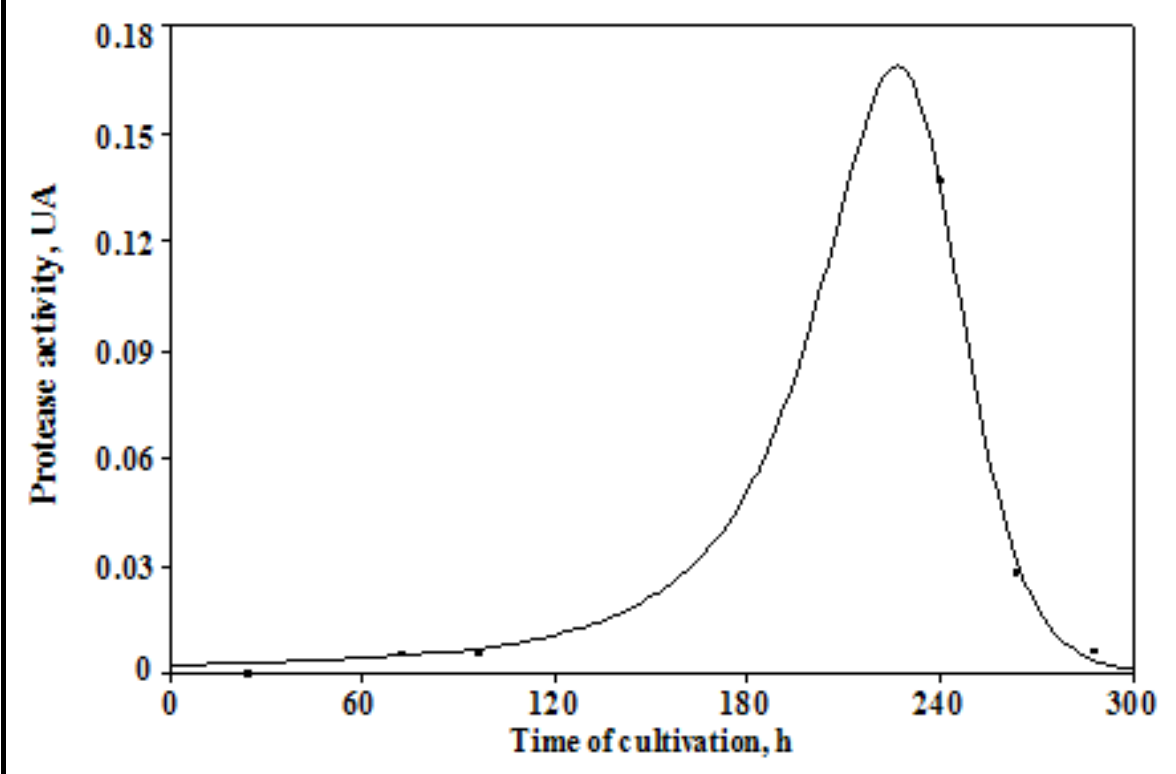

Figure 5. Proteases production at Streptomyces 4 Alga in submerged culture, by shaking at 7.276x g. Initial pH 7.0; inoculum 2\% spore suspension; incubation period: 15 days; incubation temperature $20^{\circ} \mathrm{C}$. Data are the average of two parallel replicates.

\section{DISCUSSION}

The main objective of this study was to isolate novel enzyme-producing filamentous bacteria from vegetation samples from East Antarctica, to characterize them genetically and biochemically, in order to establish their phylogeny and their ability to grow at low temperature, and to generate coldadapted amylase and proteases.

The 16S rRNA gene sequence of the new strain 4 Alga was shown to be $100 \%$ identical to the sequences of Streptomyces sp. from Norway and from the Solomon Islands. The morphological and biochemical studies also confirmed the classification of this strain in Streptomyces genus. Therefore, in accordance with the GenBank, the strains closely related with the 4 Alga are psychrophiles isolated from cold Arctic and Antarctic regions. Streptomyces sp. MP47-06 (EU263062.1) showed a $99 \%$ similarity with the 4 Alga strain and it was isolated from a Norway fjord (19).
While most of the studies are concerned about the molecular phylogeny of streptomycetes, similar attention has not been paid to their enzymology. Their ability to produce a variety of enzymes may be an attractive phenomenon in these prokaryotes (36).

A fast and accurate method has been widely used to identify newly strain using $16 \mathrm{~S}$ r DNA gene sequence analysis. This technique is important to identify organisms which are slow-growing, fastidious and where identification by conventional methods is time consuming along with subjective interpretation such as identifying streptomycetes. Castillo et al. (2003) had Streptomyces sp. NRRL 30566, which produced novel antibiotic Kakadumycins using this method (17).

The Streptomyces 4 Alga strain grew properly at low temperatures. The data showed that the Streptomyces 4 Alga was capable to easily adapt to submerged cultivation and reached the stationary phase after the five days of submerged cultivation at $20^{\circ} \mathrm{C}$. 
Alpha-amylase production was recorded after $216 \mathrm{~h}$ of cultivation, in the middle of the stationary phase. After that the amylase biosynthesis potential remains constant and after 12 days of cultivation amylase biosynthesis slowly decreased. Beta-amylase synthesis started in the middle of the stationary phase and it was achieved after $168 \mathrm{~h}$ of submerged cultivation. The maximum proteases biosynthesis was revealed after nine days of submerged cultivation. These results are in accordance with previously reported literature results (Yang and Wang, 2000) which also confirm that the biosynthesis of proteases was detected before amylase production, at Streptomyces rimosus.

Streptomyces 4 Alga was highly competent to grow in cold conditions and to biosynthesize amylase and proteases cold-adaptive at low temperature $\left(20^{\circ} \mathrm{C}\right)$.

The amylases and proteases generated by this coldadapted streptomycete strain could be valuable candidates in competitive bioremediation of polluted soils and waste waters when the metabolic ability of the endogenous microflora is reduced due to low temperatures. These enzymes might also have tremendous applications in other industrial processes, which require low temperatures.

\section{ACKNOWLEDGEMENTS}

The Bioaliment Platform of Dunarea de Jos University, Galati Romania and the Department of Agriculture and Ecology, Faculty of Life Sciences, University of Copenhagen, Denmark have been provided high scientific conditions of researches. The research was financed by the Romanian Polar Research Institute with support of UEFISCSU, contract no.1 Europolar/29.03.2010 funded by the Executive Unit for Funding of High Level Education and of Universities Scientific Research, Romania (U.E.F.I.S.C.S.U.) in the frame of the contract no.1 Europolar 2009-2010.

\section{REFERENCES}

1. Ahmed, S.A.; Ramadan, A.A.; El-Shayeb, N.M.A.; Radwan H.H.; Saleh,
S.A. (2008). Optimization, Immobilization of Extracellular Alkaline Protease and Characterization of its Enzymatic Properties. Res. J. Agricul. Biol. Sci. 4, 434-446.

2. Anson, M.L. (1938). The estimation of pepsin, trypsin, papain and cathepsin with hemoglobin. J. Gen. Physiol. 22, 79-89.

3. Bascaran, V.; Hardisson, C.; Brana, A.F. (1990). Regulation of extracellular protease production in Streptomyces clavuligerus. Appl. Microbiol. Biotechnol. 34, 208-213.

4. Bahrim G.; Scintee (Cotarlet) M.; Negoita T. (2007). Biotechnological conditions of amylase and protease complex production and utilisation involving filamentous bacteria. The Annals of the University Dunarea de Jos Galati, Fascicle IV-Food Technology, New Series, Year I (XXX), 76-82.

5. Burg, B. (2003). Extremophiles as a source for novel enzymes. Curr Opin Microbiol. 6, 213-218.

6. Chakraborty, S.; Khopade, A.; Kokare, C.; Mahadik, K.; Chopade, B. (2008). Isolation and characterization of novel $\alpha$-amylase from marine Streptomyces sp.D1. J. Molecul Cat B: Enzym. 58, 17-23.

7. Cotarlet, M.; Bahrim, G.; Negoita, T.; Stougaard, P. (2008). Screening of polar streptomycetes able to produce cold-active hydrolytic enzymes using common and chromogenic substrates. Rom Biotechnol Lett. 13, 6980 .

8. Cui, L.; Du, G.; Zhang, D.; Chen, J. (2008). Thermal stability and conformational changes of transglutaminase from a newly isolated Streptomyces hygroscopicus. Biores. Technol. 99, 3794-3800.

9. De Azeredo, L.A.I.; Castilho, L.R.; Leite, S.G.F.; Coelho, R.R.R.; Freire, D.M.G. (2003). Protease Production by Streptomyces sp. Isolated from Brazilian Cerrado Soil. Optimization of Culture Medium Employing Statistical Experimental Design. Appl Biochem Biotech.105-108, 749755.

10. Dastager, S.G.; Lee, J.C.; Ju, Y.J.; Park, D.J.; Kim, C.J. (2008). Nocardioides halotolerans sp. nov., isolated from soil on Bigeum Island, Korea. Syst Appl Microbiol. 31, 24-29.

11. Dube, M.; Schäfer, C.; Neidhart, S.; Carle, R. (2006). Texturisation and modification of vegetable proteins for food applications using microbial transglutaminase. Springer-Verlag, http://www.aseanfood.info/Articles /11019737.pdf.

12. Fairbairn, D.A.; Priest, F.G.; Stark J.R. (1986). Extracellular amylase sinthesis by Streptomyces limosus. Enzyme Microb Tech. 8, 89-92.

13. Feller, G.; Gerday, C. (2003). Psychrophilic enzymes: hot topics in cold adaptation. Nat rev/Microbiol. 1, 200-208.

14. Folin, O. and Ciocalteau, V. (1929). On tyrosine and tryptophane determinations in proteins. J. Biol. Chem. 73, 627.

15. Fujiwara S. 2002. Extremophiles: Developments of their special function and potential resources. J. Biosci Bioeng. 94, 518-525.

16. Gerday, C.; Aittaleb, M.; Bentahir, M.; Chessa, J.P.; Claverie, P., et al. (2000). Cold-adapted enzymes: from fundamentals to biotechnology. 
TIBTECH. 18, 103-107.

17. Ghadin, N.; Zin, N.M.; Sabaratnam, V.; Badya, N. (2008). Izolation and characteriztion of a novel endophytic Streptomyces SUK 06 with antimicrobial activity from malaysian plant. Asian J Plant Sci. 7, 189194.

18. Hogue, M.M.; Khaman, M.; Shiekh, M.A. (2006). Characterization and optimization of $\alpha$-amylase activity of Streptomyces clavifer. Pak. J. Biol. Sci. 9, 1328-1332.

19. Jorgensen, H.; Fjaervik, E.; Hakvag, S.; Bruheim, P.; Bredholt, H.; Klinkenberg, G.; Ellingsen,T.E.; Zotchev, S.B. (2009). Candicidin biosynthesis gene cluster is widely distributed among Streptomyces spp. isolated from the sediments and the neuston layer of the Trondheim fjord, Norway. Appl Environ Microbiol.75, 3296-3303.

20. Kamoun, A.S.; Haddar, A.; Ali, N.E.H; Frikha, B.G; Kanoun, S.; Nasri, M. (2008). Stability of thermostable alkaline protease from Bacillus licheniformis RP1 in commercial solid laundry detergent formulations. Microbiol. Res.163, 299-306.

21. Kim, S.B; Falconer, C.; Williams, E.; Goodfellow, M. (1998). Streptomyces thermocarboxydovorans $\mathrm{sp}$. nov. and Streptomyces thermocarboxydus sp. nov., two moderately thermophilic carboxydotrophic species from soil. Int. J. Syst. Bacteriol. 48, 59-68.

22. Lane, D.J. (1991). 16S/23S rRNA sequencing. In: Stackebrandt E, Goodfellow M (eds) Nucleic acid techniques in bacterial systematics. Wiley, New York, pp 115-175.

23. Lazim, H.; Mankai, H.; Slama, N.; Barkallah, I.; Limam, F. (2009). Production and optimization of thermophilic alkaline protease in solidstate fermentation by Streptomyces sp. CN902. J Ind Microbiol Biotechnol. 36, 531-537.

24. Macedo, J.A. (2007). Optimization of medium composition for transglutaminase production by a Brazilian soil Streptomyces sp. Electronic J Biotechnol.10:618-626.

25. Madigan, M.; Martinko, O, J. (2005). Brock Biology of Microorganisms, 11 Editions, Publisher Benjamin Cummings.

26. Margesin, R.; Shinner, F. (1999). Biotechnological Applications of ColdAdapted Organisms, Heidelberg: Springer-Verlag Berlin.

27. Marx, J.C.; Collins, T.; D’Amico, S.; Feller, G.; Gerday, C. (2006). Cold-adapted enzymes from marine Antarctic Microorganisms. Marin. Biotechnol., 293-304.

28. Metha, V.J.; Trumar, J.T.; Singh, S.P. (2006). Production of alkaline protease from an alkalophilic actinomycete. Biores. Technol. 97, 16501654 .
29. Moreira, K.A.; Cavalcanti, M.T.; Duarte, H.S.; Tambourgi, E.B.; Silva, V.L.; Porto, A.L.; Filho, J.L. (2001). Partial characterization of proteases from streptomyces clavuligerus using an inexpensive medium. Braz. J. Microbiol. 32, 23-28.

30. Ozer, B.; Kirmaci, H.A.; Oztekin, S.; Hayaloglu, A.; Atamer, M. (2007). Incorporation of microbial transglutaminase into non-fat yogurt production. Int Dairy J. 17, 199-207.

31. Park, J.W.; Oh, Y.S.; Lim J.Y; Roh, D.H. (2006). Isolation and Characterization of Cold-adapted strains producing $\beta$-galactosidase. $J$. Microbiol. 4, 396-402.

32. Ranganan, S. (1977). Handbook of analysis and quality control for fruit and vegetable products. Second edition. Tata McGram-Hill Publishing Company Limitated, pp 17-18.

33. Rob, A.H. (1992). A perspective on the biotechnological potential of extremophiles. Trends. Biotechnol. 10, 395-402.

34. 23. Syed, D.G.; Agasar, D.; Pandey, A. (2009). Production and partial purification of $\alpha$-amylase from a novel isolate Streptomyces gulbargensis. J. Ind. Microbiol. Biotechnol. 36, 189-194.

35. Sivaramakrishnan, S.; Gangadharan, D.; Nampoothiri, M. K.; Soccol, C.R.; Pandey, A. (2006). $\alpha$-amylases from microbial sources - an overview on recent developments. Food Technol. Biotechnol. 44, 173184.

36. Thumar, J.T.; Singh, S.P. (2007). Secretion of an alkaline protease from a salt- tolerant and alkaliphilic, Streptomyces clavuligerus strain mit-1. Braz. J. Microbiol. 38, 766-772.

37. Umezawa, Y.; Ohtsuka, T.; Yokoyama, K.; Nio, N. 2002. Comparison of Enzymatic Properties of Microbial Transglutaminase from Streptomyces sp. Food Sci Technol Res. 8, 113-118.

38. Vonothini, G.; Murugan, M.; Sivakumar, K.; Sudha, S. (2008). Optimization of protease production by an actinomycete strain, PS-18A isolated from an estuarine shrimp pond. African J. Biotechnol. 18, 32253230 .

39. www.biolog.com. Accessed 26 October 2009.

40. Yang, S.S.; Wang, J.Y. (2000). Protease and amylase production of Streptomyces rimosus in submerged and solid state cultivations. Bot. Bull. Acad. Sin. 40, 259-265.

41. Zhang, Y.; Menga, K.; Wang, Y.; Luoa, H.; Yang, P.; Shi, P.; Wu, N.; Fan, Y.; Li, J.; Yao, B. (2008). A novel proteolysis-resistant lipase from keratinolytic Streptomyces fradiae var. k11. Enzyme Microb. Tech. 42, $46-352$. 